\title{
Growth evaluation of native tree species planted on post coal mining reclamation site in East Kalimantan, Indonesia
}

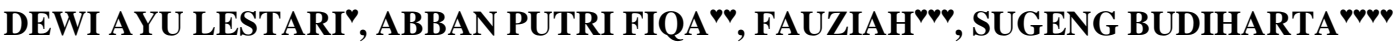 \\ Purwodadi Botanic Gardens, Indonesian Institute of Sciences. Jl. Raya Surabaya-Malang Km. 65, Purwodadi, Pasuruan 67163, East Java, Indonesia.

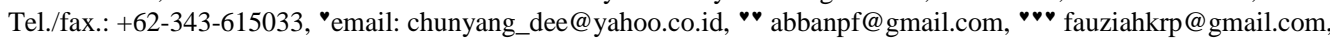 \\ rvvs sugengbudiharta@yahoo.com
}

Manuscript received: 26 October 2018. Revision accepted: 6 December 2018.

\begin{abstract}
Lestari DA, Fiqa AP, Fauziah, Budiharta S. 2019. Growth evaluation of native tree species planted on post coal mining reclamation site in East Kalimantan, Indonesia. Biodiversitas 20: 134-143. Mining activities affect environmental qualities including the loss of vegetation cover and the damages of physical, chemical and biological properties of soil. As such, regulations enacted by the Indonesian Government state a legal obligation for mining companies to carry out reclamation on post coal mining site. Reclamation is an activity carried out to organize, restore and improve of environmental quality after mining operations to enhance the highly disturbed ecosystem of mined land into ecologically usable state. Yet, there is little body of knowledge on how to monitor the effectiveness of reclamation in improving environmental quality of ex-mining land. Aims of this study are to evaluate of the growth of native tree species planted on various types of reclamation sites in a mining concession in East Kalimantan, and to analyze the most influencing factor of their growth. Growth parameters measured in this research were plant height, stem diameter and branch-free stem height of the planted species. Micro-climatic factors and diversity of understorey plants were also measured as environmental parameters. PCA (Principal Component Analysis) analysis was conducted using PAST 4.0. statistical program. The results shows that reclamation area of post coal mining in the study site which is most suitable for local plant species, especially Shorea balangeran, has a sloping terrain. PCA shows that factor having maximum influence on growth of planted species on the reclamation site is $\mathrm{pH}$ of soil. The higher is the soil $\mathrm{pH}$ (i.e. less acid), the better is the species growth because the soil conditions in the post-coal mining area tend to be acidic. This research suggests that in post coal mining reclamation using native trees two key factors to enhance growth performance of planted species are sloping terrain so as water is not inundated and soil $\mathrm{pH}$ so as it is not too acid.
\end{abstract}

Keywords: Evaluation, growth, mine, native tree species, Principal Component Analysis, reclamation

\section{INTRODUCTION}

The mining sector, especially coal, has been the major contributor of Indonesia economy, accounting for $10 \%$ of national Gross Domestic Products with value of 1000 trillion Indonesian Rupiahs (Indonesian Bureau of Statistics 2015). The largest coal deposit of Indonesia, besides North Sumatra Province, is East Kalimantan, which accounts for almost $28 \%$ of all coal deposits of Indonesia (Ministry of Energy and Mineral Resources 2008). Over the past 10-15 years, coal production in Indonesia has been increasing from year to year.

While having positive economic impact, the increase in coal production has triggered unsettling ecological problems, including deforestation and destruction of various environmental aspects such as soil, water, biodiversity and other environmental services whenever mining operations, mainly mining closure, are not prudently conducted as required by regulation (Sheoran et al. 2010; Sonter et al. 2017; Atteridge et al. 2018). As it is known, open pit mining activities such as coal mining, can change the landscape by clearing vegetation cover and damaging physical, chemical and biological properties of soil. In particular, open pit mining can cause a decrease in soil $\mathrm{pH}$ due to removal of top soil while area is inundated with water and rock material appears on the surface
(Rochani and Damayanti 1997). The acidic soil condition affects the growth of plant species which otherwise can grow well in similar site prior to mining operation occurred. In addition, the unfavorable biotic and abiotic conditions of post mining sites also create environment in which alien species might survive while native species not. Alien species are a category of plants which might grow and thrive well in the acidic soils since they are cosmopolitan species. These harsh conditions can hinder the degraded ex-mining site to recover naturally without assisted interventions.

Responding to various ecological problems caused by mining activities, the Indonesian Government through the Decree of the Minister of Energy and Mineral Resources No.1211.K/008/M.PE/1995 and the Minister of Forestry and Plantation No.145/Kpts-II/1999, regulates the obligation to carry out reclamation on post-mining sites, in order to increase their productivity, accelerate the process of revegetation on the critically degraded sites, and to accelerate in regaining ecological functions of ex-mining areas. Based on the Regulation of the Minister of Energy and Mineral Resources No.18 of 2008 article 1 number 2, reclamation is an activity carried out to organize, restore and improve the quality of the environment and its ecosystem so that it can function again in accordance to its designation. 
In simple terms, revegetation process is the easiest way to restore productivity and vegetation cover of disturbed areas, and to improve its soil quality and microclimate (Singh et al. 2002; Sheoran et al. 2010). As with other forms of revegetation, the reclamation process also has the aim of improving environmental conditions. So far, the success of reclamation activities has been assessed based only on how much extent the degraded area caused by mining operations has been covered by vegetation, while other aspects are often overlooked (Ruiz-Jaen and Aide 2005; Herrick et al. 2006). The monitoring process is equally important in reclamation activities to assess the effectiveness of reclamation particularly as mining practitioners are faced with large investment in reclamation (Erener 2011). However, the monitoring process is rarely equipped with good planning and analysis (Block et al. 2001). The results of the analysis are important and will be the basis for determining the appropriateness and suitability of the revegetation process that has been undertaken. This research was conducted to evaluate the growth of native tree species in various coal mining reclamation sites at a mining concession in East Kalimantan, and also to analyze the factors that influence growth of plants on the reclamation areas.

\section{MATERIALS AND METHODS}

\section{Study area}

This research was conducted in March 2018 in reclamation sites of post coal-mined area of a mining concession located in Muara Begai Village, Muara Lawa Sub-district, East Kutai Regency, East Kalimantan, Indonesia (Figure 1). Research was conducted in 8 research plots of the reclamation area with different vegetation characteristics and conditions (Figure 2). The plots were distinguished based on the presence or absence of shade species, planted species and slope of plot area. Reclamation area is a combination of flat and sloping areas. In addition to the mined area, the reclaimed area is the one that used to be a coal stockpile area before being transported and a refueling area. A coal stockpile area and refueling area are usually flat and has a compact soil, while the mined area was usually sloping. The reclamation process is carried out by adding top soils to ex-mining area, then in the several locations in reclamation area planted by shade trees as a pioneer before the native trees, while the others are not. This different method was used to find out the best planted pattern for the reclamation area to plant the native species. Species of shade trees choosen is local fast growing species (i.e., Duabanga moluccana and Vitex pinnata), while understorey plants living in the reclamation area grows spontaneously.

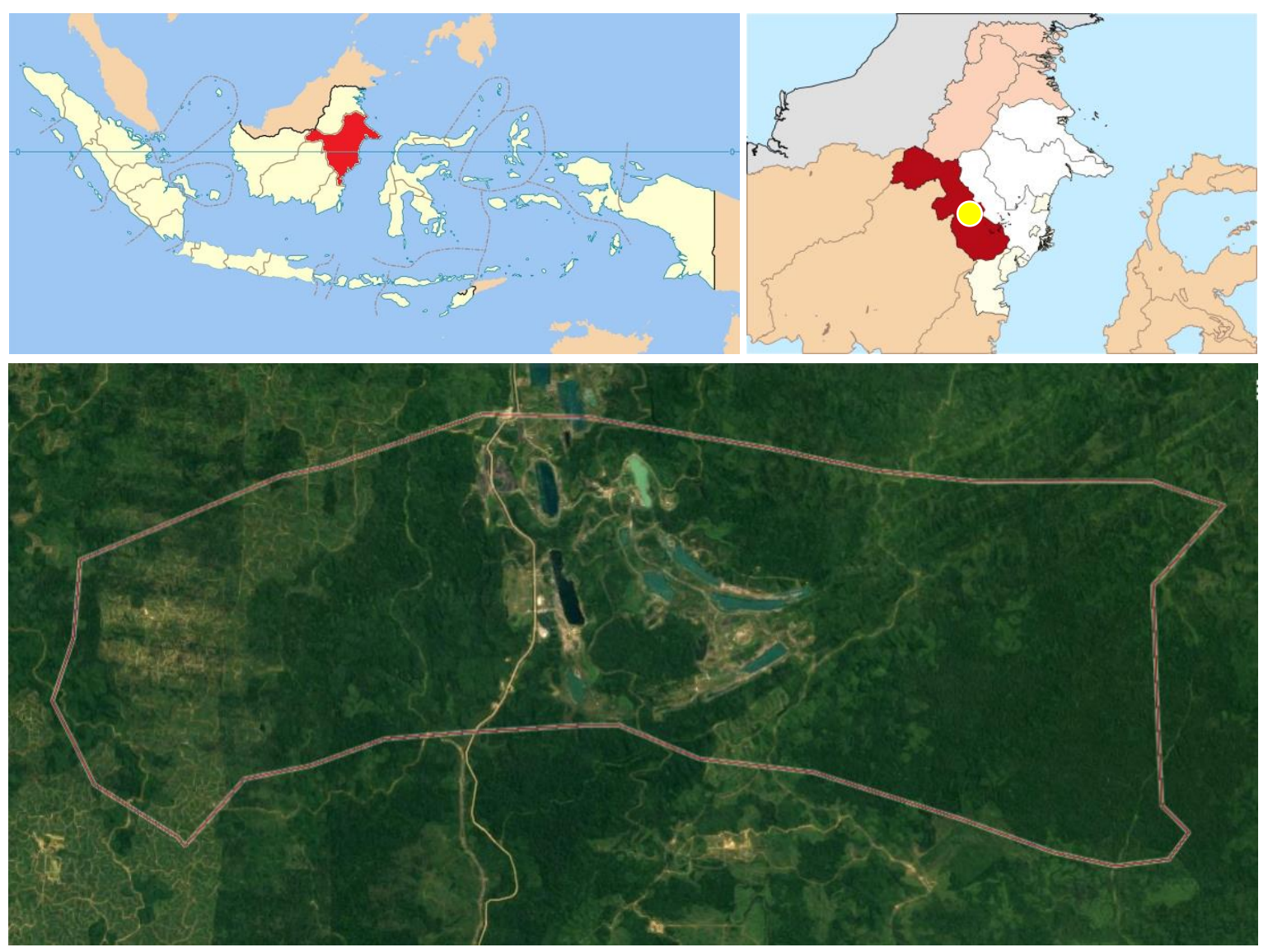

Figure 1. Location of study area in Muara Begai Village, Muara Lawa Sub-district, East Kutai Regency, East Kalimantan, Indonesia 


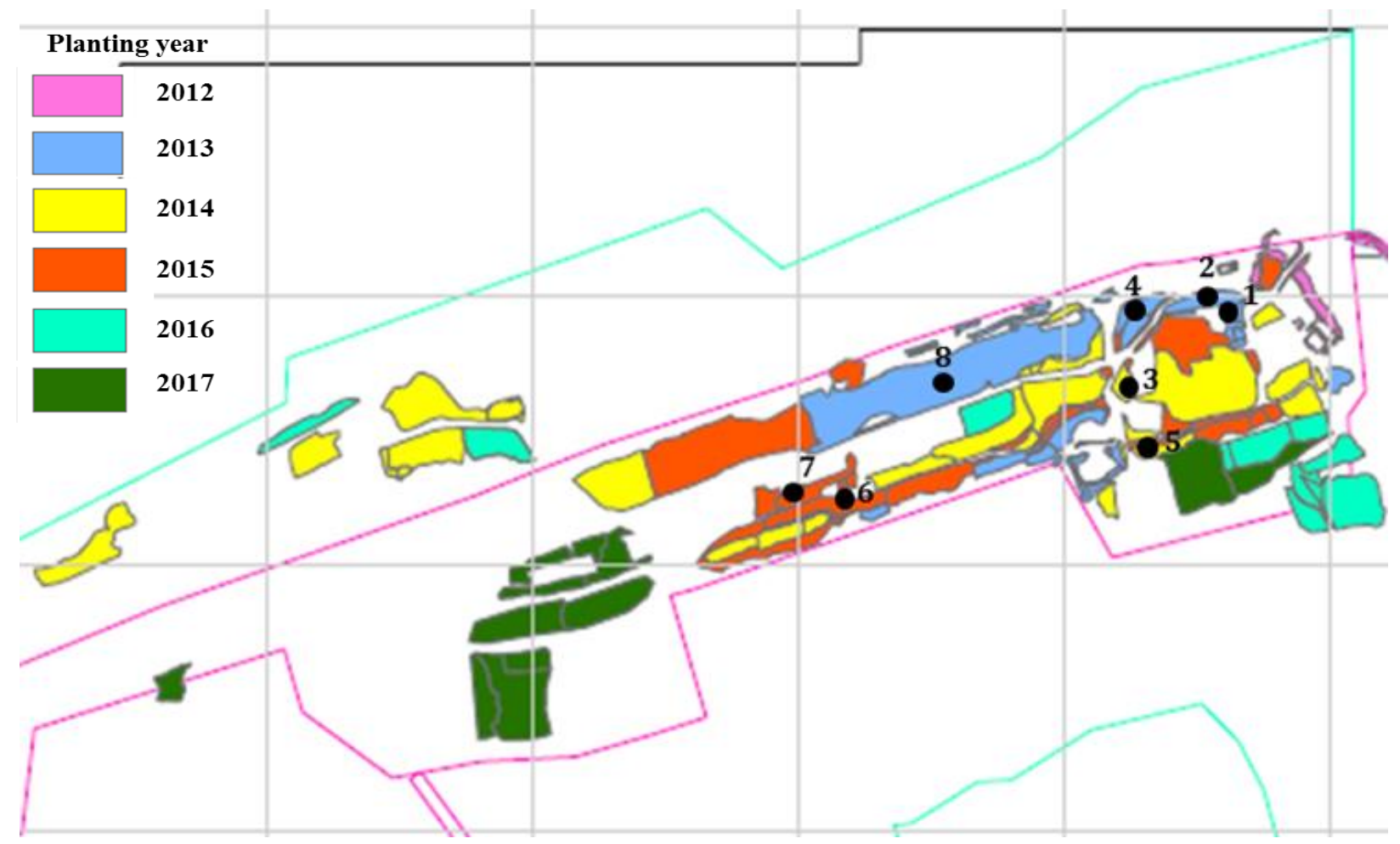

Figure 2. Observation plots in reclamation site of the study area: 1. Enterolobium cyclocarpum as shade trees, 2. Anthocephalus chinensis as shade trees, 3. Anthocephalus chinensis as shade trees, 4. Enterolobium cyclocarpum, Anthocephalus chinensis and Albizia saman as shade trees, 5 . without shade trees and on $60^{\circ}$ sloping terrain, 6 . without shade species and on $30^{\circ}$ sloping terrain, 7 . without shade trees and on flat terrain, and 8 . without shade trees and flat terrain

\section{Data collection procedure}

Survival and adaptation of plants in reclamation area

Observations were made in each of the selected plots in the coal mine reclamation area (Figure 2). As many as 30 planted native tree species were observed per observation plot. Each plant was marked with a label and map (drawn, measured in height and marked with coordinates) to facilitate the monitoring process periodically, to determine plant survival, and to find out their adaptation on the reclamation area.

According to the Ministry of Forestry Regulation 2009, success of reclamation is evaluated through an assessment of the percentage of plant survival, plant species composition and plant growth or plant health. Survival and adaptation of plants planted on reclamation sites was assessed through measurement of stem diameter, plant height and branch-free stem height of each plant. Stem diameter measurements were taken at a distance of $20 \mathrm{~cm}$ from the base of the stem using a roll meter, while the plant height and branch-free stem height were measured using roll meter and stick assistance (Alday et al. 2016). Microclimate data including temperature, humidity, light intensity and soil $\mathrm{pH}$ were also recorded for each plot. Soil $\mathrm{pH}$ is commonly used as an indicator of mine soil quality (Sheoran et al. 2010).

\section{Diversity of understorey plants in reclamation area}

The presence of understorey plants along with the planted species on the reclamation area is one of the indicators of the reclamation process (Mudrak et al. 2010). Diversity of the understorey plants grown on each plot of the reclamation area was studied by making quadrates with size of $1 \mathrm{~m} \times 1 \mathrm{~m}$. The parameters recorded were the species names of understorey plants and their abundance using scoring method.

\section{Data analysis}

Survival and adaptation of planted native tree species was related with diversity of understorey plants, besides the presence of shade tree and slope of reclamation area. Data were analyzed by descriptive method to find out the plant species that grow well on reclamation area conditions and the conditions suitable for their growth. It is important to note that post-coal mining reclamation area has a different biotics and abiotic conditions compared to conditions prior to mining. The most influencing factor for plant growth on post-coal mining reclamation area was determined by Principal Component Analysis (PCA) using the statistical program PAST 4.0. 


\section{RESULTS AND DISCUSSION}

Most of the species planted in post-coal mining reclamation area are native tree species from Indonesia, especially belonging to the family Dipterocarpaceae. They are: Dryobalanops sumatrensis, Dryobalanops oblongifolia, Duabanga moluccana, Dyera costulata, Eusideroxylon zwagerii, Ficus racemosa, Neonauclea purpurea, Neolamarckia macrophylla, Palaquium gutta, Shorea lamellata, Shorea balangeran, Shorea smithiana, Shorea leprosula, and Vitex pinnata. These species were planted in different plots of reclamation area having different shade tree and planting area conditions.

\section{Survival and adaptation of plants in reclamation area}

Data regarding survival and adaptation of planted species observed in each plot of the reclamation area are shown in Table 1.

Table 1. Growth parameters of planted species and diversity of understorey cover in eight observation plots of post-coal mining reclamation site of the study area

\begin{tabular}{|c|c|c|c|c|c|c|c|c|c|}
\hline No & Species & $\begin{array}{c}\mathbf{H} \\
(\mathbf{c m})\end{array}$ & $\begin{array}{c}\text { D } \\
(\mathbf{c m})\end{array}$ & $\begin{array}{l}\text { BFS } \\
(\mathbf{c m})\end{array}$ & $\begin{array}{c}\text { Diversity of } \\
\text { understorey } \\
\text { plants }\end{array}$ & $\begin{array}{c}\text { Slope } \\
\left({ }^{\circ}\right)\end{array}$ & $\begin{array}{l}\text { Shade tree } \\
(0=\text { absence; } \\
1=\text { presence })\end{array}$ & $\begin{array}{c}\text { Inundating water } \\
(0=\text { absence; } \\
\text { 1=presence })\end{array}$ & $\begin{array}{c}\text { Planting } \\
\text { year }\end{array}$ \\
\hline \multicolumn{10}{|c|}{ Plot 1} \\
\hline 1 & Shorea lamellata & 138.1 & 1.5 & 77.6 & 5 & 0 & 1 & 0 & 2015 \\
\hline 2 & Eusideroxylon zwageri & 63.4 & 0.9 & 31.7 & 5 & 0 & 1 & 0 & 2015 \\
\hline 3 & Dryobalanops oblongifolia & 128.0 & 0.9 & 103.5 & 5 & 0 & 1 & 0 & 2015 \\
\hline 4 & Shorea balangeran & 146.0 & 1.5 & 77.0 & 5 & 0 & 1 & 0 & 2015 \\
\hline 5 & Shorea leprosula & 125.0 & 1.8 & 22.0 & 5 & 0 & 1 & 0 & 2015 \\
\hline \multirow{2}{*}{\multicolumn{10}{|c|}{$\begin{array}{l}\text { The dominant understorey plants are Asystasia gangetica and Paspalum conjugatum } \\
\text { Plot } 2\end{array}$}} \\
\hline & & & & & & & & & \\
\hline 1 & Shorea lamellata & 141.2 & 2.0 & 66.1 & 6 & 30 & 1 & 0 & 2015 \\
\hline 2 & Dryobalanops oblongifolia & 161.5 & 1.6 & 103.3 & 6 & 30 & 1 & 0 & 2015 \\
\hline 3 & Eusideroxylon zwageri & 72.5 & 1.0 & 26.4 & 6 & 30 & 1 & 0 & 2015 \\
\hline \multicolumn{10}{|c|}{ The dominant understorey plant is Paspalum conjugatum } \\
\hline \multicolumn{10}{|c|}{ Plot 3} \\
\hline 1 & Shorea lamellata & 139.2 & 1.6 & 77.0 & 5 & 0 & 1 & 0 & 2016 \\
\hline \multicolumn{10}{|c|}{ The dominant understorey plant is Calopogonium mucunoides } \\
\hline \multicolumn{10}{|c|}{ Plot 4} \\
\hline 1 & Shorea lamellata & 137.0 & 2.2 & 79.1 & 5 & 0 & 1 & 0 & 2016 \\
\hline 2 & Palaquium gutta & 30.0 & 0.4 & 0.0 & 5 & 0 & 1 & 0 & 2016 \\
\hline 3 & Dryobalanops oblongifolia & 34.0 & 0.8 & 26.0 & 5 & 0 & 1 & 0 & 2016 \\
\hline \multicolumn{10}{|c|}{ The dominant understorey plant is Paspalum conjugatum } \\
\hline \multicolumn{10}{|l|}{ Plot 5} \\
\hline 1 & Shorea balangeran & 211.2 & 3.5 & 60.6 & 7 & 60 & 0 & 0 & 2015 \\
\hline 2 & Duabanga moluccana & 147.3 & 2.9 & 76.3 & 7 & 60 & 0 & 0 & 2015 \\
\hline 3 & Neolamarckia macrophylla & 65.0 & 0.9 & 49.0 & 7 & 60 & 0 & 0 & 2015 \\
\hline \multicolumn{10}{|c|}{ The dominant understorey plant is Paspalum conjugatum } \\
\hline \multicolumn{10}{|l|}{ Plot 6} \\
\hline 1 & Shorea balangeran & 159.0 & 2.8 & 44.1 & 8 & 30 & 0 & 0 & 2015 \\
\hline 2 & Neonauclea purpurea & 64.0 & 1.3 & 10.0 & 8 & 30 & 0 & 0 & 2015 \\
\hline 3 & Dyera costulata & 43.2 & 0.5 & 15.4 & 8 & 30 & 0 & 0 & 2015 \\
\hline 4 & Palaquium gutta & 45.0 & 0.4 & 23.0 & 8 & 30 & 0 & 0 & 2015 \\
\hline \multicolumn{10}{|c|}{ The dominant understorey plant is Paspalum conjugatum } \\
\hline \multicolumn{10}{|c|}{ Plot 7} \\
\hline 1 & Duabanga moluccana & 483.3 & 13.9 & 164.3 & 5 & 0 & 0 & 0 & 2015 \\
\hline 2 & Ficus racemosa & 71.0 & 0.8 & 28.0 & 5 & 0 & 0 & 0 & 2015 \\
\hline 3 & Shorea lamellata & 102.0 & 1.2 & 73.0 & 5 & 0 & 0 & 0 & 2015 \\
\hline 4 & Shorea smithiana & 42.0 & 1.6 & 9.0 & 5 & 0 & 0 & 0 & 2015 \\
\hline 5 & Vitex pinnata & 463.8 & 6.7 & 46.8 & 5 & 0 & 0 & 0 & 2015 \\
\hline 6 & Dryobalanops sumatrensis & 126.0 & 1.9 & 59.7 & 5 & 0 & 0 & 0 & 2015 \\
\hline 7 & Palaquium gutta & 112.7 & 3.5 & 38.3 & 5 & 0 & 0 & 0 & 2015 \\
\hline \multicolumn{10}{|c|}{ The dominant understorey plant is Centrosema pubescens } \\
\hline \multicolumn{10}{|c|}{ Plot 8} \\
\hline 1 & Dryobalanops sumatrensis & 83.8 & 0.6 & 35.4 & 6 & 0 & 1 & 1 & 2014 \\
\hline 2 & Shorea balangeran & 149.7 & 3.0 & 48.0 & 6 & 0 & 1 & 1 & 2014 \\
\hline 3 & Dyera costulata & 81.0 & 0.7 & 71.0 & 6 & 0 & 1 & 1 & 2014 \\
\hline The d & nant understorey plant is Calo & ogoniu & тиси & oides & & & & & \\
\hline
\end{tabular}

Note: $\mathrm{H}=$ plant height, $\mathrm{D}=$ stem diameter, BFS=branch-free stem height 


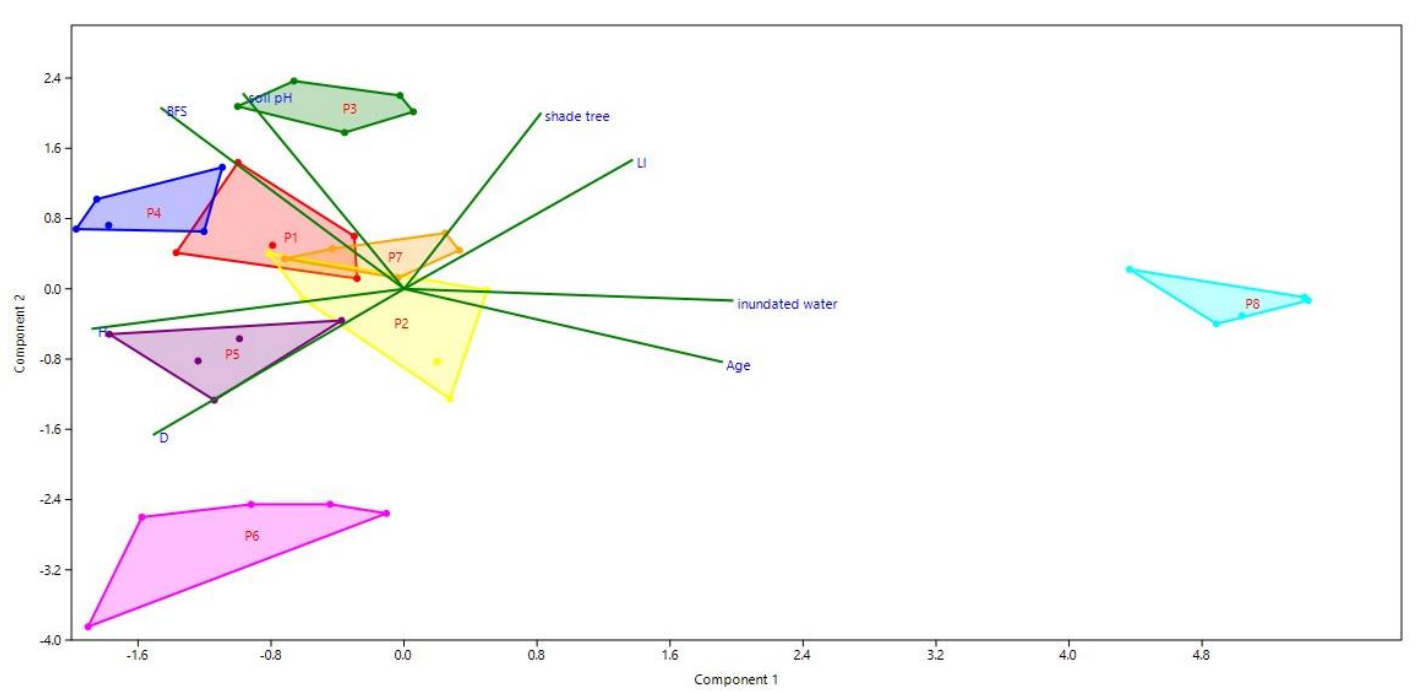

Figure 4. Biplot showing the influence of environmental factors on plant growth in reclamation area. Observation plots are displayed with symbols P1 to P8. Value of component 1 explain $56.72 \%$ of all environmental factors observed, while component 2 explain $25.95 \%$. The influential environmental factors and abbreviations are explained in Table 3.

Table 2. Microclimatic factors in reclamation area

\begin{tabular}{lc}
\hline \multicolumn{1}{c}{ Factors } & Value \\
\hline Temperature $\left({ }^{\circ} \mathrm{C}\right)$ & $30.2-34.7$ \\
Humidity $(\%)$ & $53-70$ \\
Light intensity (lux) & $5590-106400$ \\
Soil $\mathrm{pH}$ & $5-6$ \\
Elevation (m asl) & $104-139$ \\
\hline
\end{tabular}

Table 3. Eigenvalue of environmental factors in reclamation site of the study area

\begin{tabular}{lcc}
\hline & $\begin{array}{c}\text { PC 1 } \\
\text { (component } \\
\text { factor 1) }\end{array}$ & $\begin{array}{c}\text { PC 2 } \\
\text { (component } \\
\text { factor 2) }\end{array}$ \\
$\begin{array}{l}\text { Eigenvalue } \\
\text { Variable: }\end{array}$ & 4.54 & 2.08 \\
Environment & & \\
LI (light intensity) & 0.31 & $\mathbf{0 . 3 4}$ \\
Soil pH & -0.22 & $\mathbf{0 . 5 1}$ \\
Age of plant & $\mathbf{0 . 4 4}$ & -0.19 \\
Number of shade tree & 0.19 & $\mathbf{0 . 4 6}$ \\
Inundated water (presence & $\mathbf{0 . 4 5}$ & -0.03 \\
absence of inundated water) & & \\
Growth parameters & & \\
H (Height) & $\mathbf{- 0 . 4 3}$ & -0.10 \\
D (Diameter) & -0.35 & $\mathbf{- 0 . 3 8}$ \\
BFS (Branch-Free Stem Height) & -0.34 & $\mathbf{0 . 4 7}$ \\
\hline
\end{tabular}

Planting started in 2014 and continued regularly every year. Observations show that seedlings planted in flat terrain and inundated water area have poor growth (stagnation) when compared to those planted in a sloping terrain. This is indicated by S. balangeran planted in 2014 in plot 8 which are smaller in size than those planted in plot
5 which is sloping terrain without inundated water. Similar condition is shown by $D$. sumatraensis and D. moluccana, both planted in 2015 , have a smaller size when compared to plants of the same species in other plots (Figure 3). Average microclimate data of reclamation area is not much different from average microclimate of natural forest preserved as conservation area nearby the reclamation area (Fiqa et al. 2018, in prep), as shown in Table 2. It implies that microclimate conditions are not assumed to affect much on growing conditions.

\section{The influence of environmental factors on the growth of reclamation plants}

The influence of environmental factors (light intensity, temperature, humidity, altitude, soil $\mathrm{pH}$, slope, invasive rate of understorey plant, age of plant, sum of shade tree and inundating water) on plant growth observed (stem diameter, plant height and branch-free stem height) is shown in Figure 4 and Table 3. Plant growth varies across plots. However, plant growth on plot 8 is significantly different from other plots, as shown in Figure 3. Since the large distance between plot 8 and the other plots. Plot 8 is classified as different group to the other with a distinctive characteristic. Plant growth on plot 8 affected by the presence of inundating water which is not found in the other plots.

Beside the presence of inundation, soil $\mathrm{pH}$ is the most influencing environmental factor for plant growth on the planted trees. Soil $\mathrm{pH}$ has the highest value in both component 1 (i.e. PC 1) and 2 (i.e. PC 2) as seen in Table 3. Diameter, as one of growth parameters, shows a negative correlation with soil $\mathrm{pH}$ as shown in the PC 2. Similarly, inundated water has a negative correlation to plant height as mentioned in PC 1 . However, soil $\mathrm{pH}$ has a positive correlation to the height of branch free stem (BFS), indicating that soil $\mathrm{pH}$ might relate to branch development. 


\section{Diversity of understorey plants in reclamation area}

Understorey plants cover in observation plots of reclamation area consist of more or less same species composition. The recorded species are: Asystasia gangetica, Calopogonium mucunoides, Chromolaena odorata, Centrosema pubescens, Imperata cylindrica, Mikania cordata, Melastoma malabathricum, Paspalum conjugatum and Selaginella sp. (Figure 5). Dominant species of understorey plants in each of the observation plots is shown in Table 1. $P$. conjugatum and $C$. mucunoides are the most commonly found understorey plants in reclamation area.

\section{Discussion}

Plants species known for their survival and adaptation to different habitat conditions on the reclamation area of former coal mines are S. lamellata, S. balangeran, D. moluccana, P. gutta, D. oblongifolia and N. macrophylla. The growth performance of plants in the reclamation area of ex-mined land can be known by their increasing height and diameter as age increasing after planting (Budiana et al. 2017).
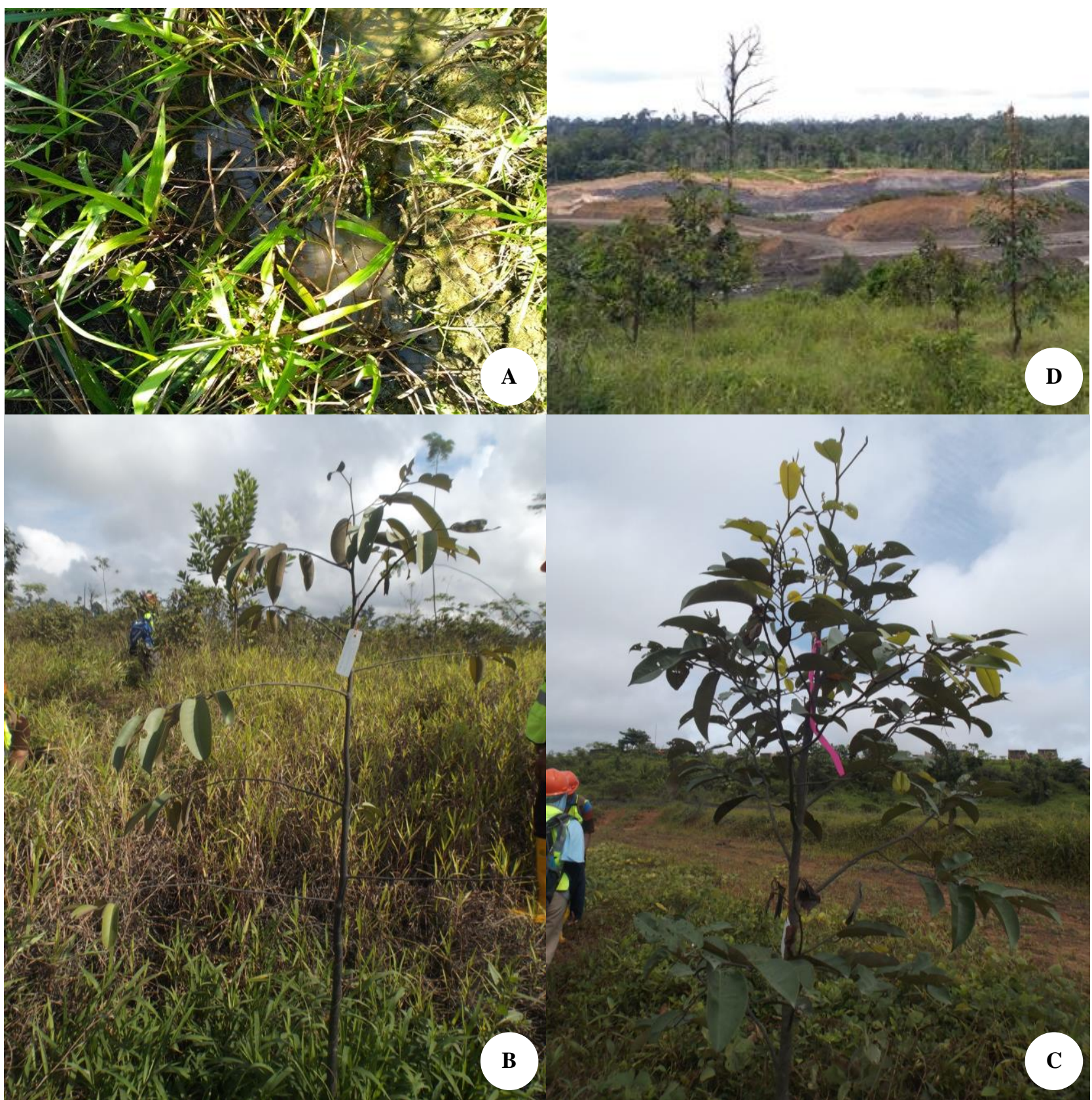

Figure 3. Comparison of growth of Shorea balangeran in different conditions of post-coal mining reclamation area; A. Flat area with inundating water, Plot 8, B. Growth condition of $S$. balangeran in flat area with inundating water, Plot 8 , C. Growth condition of $S$. balangeran in sloping terain $\left(60^{\circ}\right)$, Plot 5 , D. Sloping terain $\left(60^{\circ}\right)$ of plot 5 


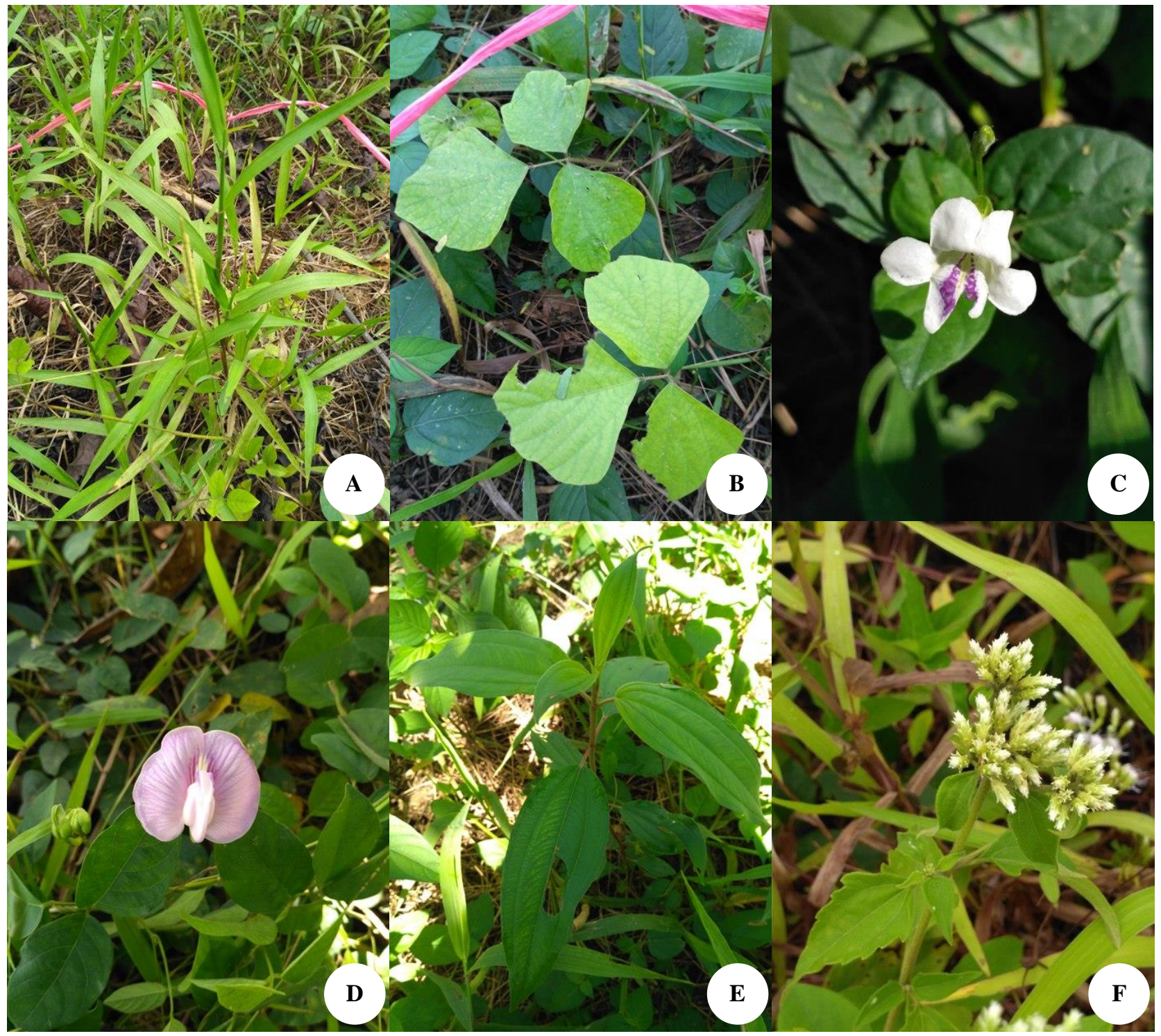

Figure 5. Most commonly found species of understorey plants in observation plots of reclamation area: A. Paspalum conjugatum, B. Calopogonium mucunoides, C. Asystasia gangetica, D. Centrosema pubescens, E. Melastoma malabathricum, and F. Chromolaena odorata

S. lamellata (white meranti) shows same growth performance in both flat or sloping terrain. This is a native plant species distributed in Sumatra, adapted to an altitude ranging from 0 to $700 \mathrm{~m}$ above sea level and capable of growing in dry land, sometimes inundated, rocky soil and sandy soil with flat to undulated topography. In areas with $25 \%$ slope, S. lamellata is found in groups (Ashton 1998a; Istomo and Afnani 2014). This species was able to grow and adapt well in the reclamation area, even though its growth is slow.

S. balangeran (red meranti) is native to Indonesia (Sumatra and Kalimantan) and generally spread in tropical primary forests which are sometimes flooded, and in swampy areas or river banks. This species has a relatively faster growth rate than other peat swamp species and is classified as an endangered commercial tree species in its natural habitat (Ashton 1998b; Suryanto et al. 2012).
Natural habitats of $S$. balangeran are lowland area of dry lands and tidal wetlands as well as peat swamp forests of gentle topography with mild wavy, slope of $0-10 \%$, temperatures ranging from $27-37^{\circ} \mathrm{C}$, humidity $50-80 \%$ and altitude 5-55 m above sea level. In general, this species can adapt to a variety of environmental conditions, such as dry land, open land, peat land and heath (Simbolon 2008; Atmoko 2011; Wardani and Susilo 2016). The results of this study suggest that $S$. balangeran is more suitable for planting in the reclamation area with a slope of $30-60^{\circ}$, compared to a flat area. Micro-climate factors like temperatures ranging from $30-34^{\circ} \mathrm{C}$, air humidity of 53$70 \%$ and altitude of 104-139 m above sea level are suitable for growth of this species. It can adapt well on flat terrain, if the soil aeration is good and there is no inundating water. For some plants species, inundating water can disrupt root 
development and nutrient uptake, and cause soil compaction when the soil is drying up (Istomo et al. 2013).

D. moluccana (binuang laki) has its habitat along the river, disturbed areas in dipterocarp forests, swamps and sub-montane forests with altitudes reaching up to $1500 \mathrm{~m}$ above sea level. This species is classified as a fast-growing pioneer plant, which can grow well and be able to adapt to harsh environmental conditions (Razak 2005). D. oblongifolia is a large tree species that can grow up to $60 \mathrm{~m}$ height. This species can grow well on inundating water soil close to the river flow (Barstow 2018). P. gutta is a species of tree that is often found in lowland Dipterocarp forests, heath forests and limestone. All the above three species of plants are able to grow and adapt to flat areas in the reclamation area, with no shade trees and inundating water.

The species planted in the reclamation area are related to understorey species. The existence of understorey plants plays an important role in the vegetation succession of post mining reclamation. These roles include maintaining soil moisture during the dry season, serving as a barrier to rainwater run-off during the rainy season and as suppliers of litter decomposing into soil organic matter contributing to the formation of top soil (Zipper et al. 2011). The understorey plants tend to be more adaptive to various types of soil conditions which could hamper the growth of planted species in obtaining nutrients from the soil, so that their presence and distribution is importance noticed. In the flat area with a low risk of erosion, use of spontaneously growing plants as an understorey is adequate for cover crop (Sena et al. 2015).

Even without reclamation, the ex-mining area can actually proceed natural succession (Mudrak et al. 2010). However, the resulting ecosystem will not return to ecologically usable state and the vegetation composition formed will be very different from before. Whether this novel ecosystem actually advantages or disadvantages in restoration ecology is still a debated issue (Hobbs et al. 2006; Hobbs et al. 2009; Murcia et al. 2014). Assisted reclamation of ex-mining areas recover faster than nonassisted ones, both in the rate of topsoil accumulation and biomass increase of plants (Pietrzykowski 2008). In the beginning of revegetation, plant's growth must be assisted from cosmopolitan alien species that are able to survive in unfavorable environmental conditions, in order to create a favorable ecosystem (Herrick et al. 2006; Vidra and Shear 2008). The presence of recolonizing species which are more adaptive and mostly invasive might disrupt the growth of local plant species in the reclamation area. Invasion by alien species occurs when exotic plants grow in areas with of environmental conditions not suitable for most species. Observations on invasive plants are most easily and quickly conducted through groundcover diversity analysis.

Asystasia gangetica is an herbaceous ornamental plant recognized as very invasive because of its rapid growth (GISD 2018). Imperata cylindrica is a weed commonly found in areas disturbed by human activities with very rapid spread (MacDonald 2004). Melastoma malabathricum is a species of weed that is often found in open spaces and areas disturbed due to plantations. This species is easily spread by animals (birds) carrying seeds. Paspalum conjugatum is very tolerant to highly acidic soil conditions. In general, the post mining reclamation areas have high soil acidity so that this species of weed is found frequently. Mikania cordata has the characteristics of rapid growth, climbing and wrapping around tree stands so that it easily kills other plants through the closure of canopy. Centrosema pubescens is classified as a perennial herbaceous plant that has a deep root penetration system, fast and aggressive growth, grows and wraps other plants. This species has the same effect on other plants as that of M. cordata. Calopogonium mucunoides is a nitrogen fixing legume species, but is classified as an invasive plant that can grow on acidic soil and dry environments. The presence of this species can strangle or kill other plants. Chromolaena odorata is a perennial herb that is not tolerant to shade and able to compete with other species as it has allelopathic compounds (Yusuf and Arisoesilaningsih 2017). M. cordata, C. pubescens and C. mucunoides are understorey plants species that needs special attention because they are highly invasive. They will be of considerable influence on the sustainability of the reclamation program because they interfere with the growth of planted species in the reclamation area, if such invasive plants are not controlled properly. Basically, increase in the number of plants in the area should no longer be the main objective of the reclamation program because if the increase is actually dominated by alien invasive species, then the stability of the ecosystem is actually disrupted (Ehrenfeld 2003; Prach and Hobbs 2008).

Inundating water that affects plant growth in the reclamation area usually occur due to poor drainage or when the landscape forming a basin (Widiyatmoko et al 2017). The presence of inundating water can disrupt plant growth because it inhibits the supply of oxygen to the soil and inhibits gas exchange between soil and atmosphere (Riche 2004; Sairam et al. 2008). In addition to inundating water, generally plant growth in the reclamation area is also influenced by soil $\mathrm{pH}$. Soil $\mathrm{pH}$ values in ex-mined areas are usually acidic (Baasch et al. 2009; Swain et al. 2011; Tapadar and Jha 2015). Acidic soil conditions inhibit plant growth to be less than optimal. The higher $\mathrm{pH}$ value (close to neutral) will be better for plant growth. Land with acidic conditions generally has high metal elements such as $\mathrm{Al}$, $\mathrm{Mn}$ and $\mathrm{Cu}$ which are toxic to plants. This will affect the availability of $\mathrm{P}$ and $\mathrm{N}$ elements due to binding to $\mathrm{Al}$ elements, which hamper plant growth (Emerson et al. 2009; Sheoran et al. 2010). Element $\mathrm{P}$ plays an important role in plant metabolism such as transfer and storage of energy. It is also an activator of various enzymes in plants so that the lack of this element will disrupt its metabolism. Meanwhile, element $\mathrm{N}$ as an essential nutrient, plays a role in the formation of protein (Hernandez and Munne-Bosch 2015; Leghari et al. 2016; Razaq et al. 2017).

Other environmental factors, besides soil $\mathrm{pH}$, such as the presence inundating water and shade trees has little influence on plant growth in the reclamation area. Liming can be an alternative solution for acidic conditions in exmining areas. Whenever liming is not feasible for large 
reclamation areas, hydroseeding may be an another solution. The hydroseeding method uses local species of plants that are able to adapt to their natural environment, so that they can grow optimally in degraded areas (Anshari et al. 2018).

The use of local plant species in the reclamation activities of ex-coal mining areas will have a positive impact on biodiversity conservation activities. This helps to accelerate the succession process to close to natural condition, maintain the genetic integrity of local plant species and increase the success of planting. In order enhance the effectiveness of planting native species, the presence of invasive plants should be controlled because they suppress the growth local plants which hamper the success of the reclamation program. The negative impact of invasive understorey will not only change the natural succession process that takes place in the reclamation area, but also has the potential to change the composition and structure of species in the ecosystem (Jordan et al 2008; Norton 2009; Pejchar and Mooney 2009; Nugroho and Yassir 2017). The use of local plant species in the reclamation of post mining areas will restore the vegetation structure close to original condition and restore the ecosystem service functions that existed prior to mining.

\section{ACKNOWLEDGEMENTS}

This research was supported by PT. Bharinto Ekatama, a subsidiary of PT. Indo Tambangraya Megah, Tbk. The authors would like to acknowledge the Director of Purwodadi Botanic Garden-Indonesian Institute of Sciences for the opportunity to conduct field activities, PT Bharinto Ekatama team for their assistance in the field and all of Purwodadi Botanic Garden fieldwork team: Matrani, Abdul Goni and Abdul Arifin for their assistance in the field for plant identification and other technical assistance.

\section{REFERENCES}

Alday JG, Zaldivar P, Balmori PT, Santos BF, Ruiz CM. 2016. Natura forest expansion on reclaimed coal mines in Northern Spain: the role of native shrubs as suitable microsites. Environ Sci Poll Res 23 (14): 13606-13616.

Anshari MF, Boedianto E, Fernandes AAR, Arisoesilaningsih E. 2018 Hydroseeding application using pioneer local plant seeds for coal post mining soil in Tanah Laut Regency, South Kalimantan. J Degraded Mining Lands Manag 5 (4): 1335-1345.

Ashton P. 1998a. Shorea lamellata. The IUCN Red List of Threatened Species 1998: e.T31971A9671513. DOI: 10.2305/IUCN.UK.1998.RLTS.T31971A9671513.en. [11 Oct 2018].

Ashton P. 1998b. Shorea balangeran. The IUCN Red List of Threatened Species 1998: e.T33103A9756028. DOI: 10.2305/IUCN.UK.1998.RLTS.T33103A9756028.en. [11 Oct 2018].

Atmoko T. 2011. The potential for regeneration and spread of Shorea balangeran (Korth.) Burck at Saka Kajang seed center, Central Kalimantan. J Dipterocarp Res 5 (2): 21-35. [Indonesia]

Atteridge A, Aung MT, Nugroho A. 2018. Contemporary coal dynamics in Indonesia. Stockholm Environment Institute, Sweden.

Baasch A, Tischew S, Bruelheide H. 2009. Insights into succession processes using temporally repeated habitat models: results from a long term study in a post-mining landscape. J Veg Sci 20: 629-638.

Barstow M. 2018. Dryobalanops oblongifolia. The IUCN Red List of Threatened Species 2018: e.T63023A68070307. DOI:
10.2305/IUCN.UK.2018-1.RLTS.T63023A68070307.en. [12 October $2018]$.

Block WM, Franklin AB, Ward JP, Ganey JI Jr, White GC. 2001. Design and implementation of monitoring studies to evaluate the success of ecological restoration on wildlife. Restor Ecol 9 (3): 293-303.

Budiana IGE, Jumani, Biantary MP. 2017. Evaluation of the success rate of revegetation of ex-coal mine land in PT Kitadin East Kalimantan District Kutai Kartanegara Embalut Site. Journal AGRIFOR XVI (2): 195-208. [Indonesia]

Decree of Ministry of Energy and Mineral Resource. 2008. Energy and Mineral Resources Data and Information Center. http://www.esdm.go.id/. Accessed on 22 Oktober 2018.

Decree of Ministry of Forestry. 2009. No. P.60/Menhut-II/2009. Regarding Guidelines for Assessing the Success of Forest Reclamation. Ministry of Forestry, Jakarta.

Ehrenfeld JG. 2003. Effects of exotic plant invasions on soil nutrient cycling processes. Ecosystems 6 (6): 503-523.

Emerson P, Skousen J, Ziemkiewicz P. 2009. Survival and growth of hardwoods in brownversus grey sandstone on a surface mine in West Virginia. J Environ Qual 38: 1821-1829.

Erener A. 2011. Remote sensing of vegetation health for reclaimed area of Seyotomer open cast coal mine. Int J Coal Geol 86: 20-26.

Fiqa AP, Fauziah, Lestari DA, Budiharta S. 2018. The importance of insitu conservation area mining concession in preserving diveristy, threatened and potential floras in East Kalimantan. in prep.

Global Invasive Species Database (GISD). 2018. Species profile: Asystasia gangetica. http://www.iucngisd.org/gisd/species.php?sc=1273. Accessed on 10 October 2018.

Hernandez I, Munne-Bosch S. 2015. Linking phosphorous availability with photo-oxidative stress in plants. J Exp Bot 66 (10): 2889-2900.

Herrick JE, Schuman GE, Rango A. 2006. Monitoring ecological processes for restoration projects. J Nat Conserv 14: 161-171.

Hobbs RJ, Arico S, Aronson J,Baron JS, Bridgewater P, Cramer VA, Epstein PR, Ewel JJ, Klink CA, Lugo AE, Norton D, Ojima D, Richardson DM, Sanderson EW, Valladares F, Vilà M, Zamora R, Zobel M. 2006. Novel ecosystems: theoretical and management aspects of the new ecological world order. Glob Ecol Biogeogr 15: 17.

Hobbs RJ, Higgs E, Harris JA. 2009. Novel ecosystems: implications for conservation and restoration. Trends Ecol Evol 24 (11): 599-605.

Indonesian Bureau of Statistics. 2015. National Income of Indonesia 2010-2014. https://www.bps.go.id/index.php/publikasi/1032. [26 November 2018].

Istomo, Afnani M. 2014. Potency and distribution of meranti (Shorea spp.) in protected area of PT Wana Hijau Pesaguan, West Kalimantan. Jurnal Silvikultur Tropika 5 (3): 196-205. [Indonesia]

Istomo, Setiadi Y, Putri AN. 2013. Evaluation of the success result plants revegetation in coal post-mining land Lati Site PT Berau Coal East Kalimantan. Jurnal Silvikultur Tropika 4 (2): 77-81. [Indonesia]

Jordan NR, Larson DL, Huerd SC. 2008. Soil modification by invasive plants: effects on native and invasive species of mixed-grass prairies. Biol Invasions 10 (2): 177-190.

Leghari SJ, Wahocho NA, Laghari GM, Talpur KH, Wahocho SA, Lashari AA. 2016. Role of nitrogen for plant growth and development: a review. Adv Environ Biol 10 (9): 209-218.

MacDonald GE. 2004. Cogongrass (Imperata cylindrica)-Biology, ecology and management. J Crit Revi Plant Sci 23 (5): 367-380.

Ministry of Energy and Mineral Resources. No. 18/2008. Reclamation and Mine Closure. Ministry of Energy and Mineral Resources, Jakarta [Indonesian]

Mudrak O, Frouz J, Velichova V. 2010. Understory vegetation in reclaimed and unreclaimed post mining forest stands. Ecol Engineer 36: 783-790.

Murcia C, Aronson J, Kattan GH, Moreno-Mateos D, Dixon K,Simberloff D. 2014. A critique of the 'novel ecosystem' concept. Trends Ecol Evol 29 (10): 548-553.

Norton DA. 2009. Species invasions and the limits to restoration: learning from the New Zealand experience. Science 325 (5940): 569-571.

Nugroho AW, Yassir I. 2017. Policy study on post coal mining reclamation assessment in Indonesia. Jurnal Analisis Kebijakan Kehutanan 14 (2): 121-136. [Indonesian]

Prach K, Hobbs RJ. 2008. Spontaneous succession versus technical reclamation in the restoration of disturbed sites. Restor Ecol 16 (3): 363-366. 
Pejchar L, Mooney HA. 2009. Invasive species, ecosystem services and human well-being. Trends Ecol Evol 24 (9): 497-504.

Pietrzykowski M. 2008. Soil and plants communities development and ecological effectiveness of reclamation on a sand mine cast. J For Sci 54 (12): 554-565.

Razak HA. 2005. Biodegradation Characteristics of Duabanga moluccana Blume and Endospermum diadenum (Miq.) Airy Shaw. [Thesis]. University of Malaysia Sarawak, Malaysia.

Razaq M, Zhang P, Shen HI, Salahuddin. 2017. Influence of nitrogen and phosphorous on the growth and root morphology of Acer mono. PloS $\begin{array}{llll}\text { ONE } & 12 & \text { (2): } & \text { e171321. }\end{array}$ https://doi.org/10.1371/journal.pone.0171321.

Riche CJ. 2004. Identification of soybean cultivars tolerance to waterlogging through analyses of leaf nitrogen concentration. [Thesis]. Lousiana State University, Lousiana. http://etd.lsu.edu/docs/available/etd-04132004154236/unrestricted/Riche_thesis.pdf. Accessed on 22 October 2018.

Rochani S, Damayanti R. 1997. Acid main drainage: general overview and strategies to control impacts. Indones Mining J 3 (2): 36-42.

Ruiz-Jaen MC, Aide TM. 2005. Restoration success: How is it being measured? Restor Ecol 13 (3): 569-577.

Sairam RK, Kumutha D, Ezhilmathi K, Deshmukh PS, Srivastava GC. 2008. Physiology and biochemistry of waterlogging tolerance in plants. Biol Plant 52: 401-412.

Sena K, Barton C, Hall S, Angel P, Agouridis C, Warner R. 2015. Influence of spoil type of afforestation success and natural vegetative recolonization on a surface coal mine in Appalachia, United States. Restor Ecol 23:131-138.

Sheoran V, Sheoran AS, Poonia P. 2010. Soil reclamation of abandoned mine land by revegetation: a review. Int J Soil Sediment Water 3 (2): $1-20$.

Simbolon H. 2008. Tree population of Dipterocarpaceae species in three types of Kalimantan forest. Berita Biologi 9 (1): 45-57. [Indonesia]
Singh AN, Raghubanshi AS, Singh JS. 2002. Plantations as a tool for mine spoil restoration. Curr Sci 82: 1436-1441.

Sonter LJ, Herrera D, Barrett DJ, Galford GL, Moran CJ, Soares-Filho BS. 2017. Mining drives extensive deforestation in the Brazilian Amazon. Nature Communications 8: 1013. DOI: 10.1038/s41467017-00557-w.

Suryanto TS, Hadi E, Savitri. 2012. Get to know Shorea balangeran. In Cultivating Shorea balangeran on Peatlands. Ministry of Forestry. Forestry Research and Development Agency. Forestry Research Institute of Banjarbaru, South Kalimantan. [Indonesia]

Swain BK, Goswami S, Das M. 2011. Impact of mining on soil quality: a case study from Hingula opencast coal mine, Angul district, Orissa. Vistas Geol Res 10: 77-81.

Tapadar SA, Jha DK. 2015. Influence of open cast mining on the soil properties of Ledo Colliery of Tinsukia district of Assam, India. Int J Sci Res Publications 5 (3): 1-5.

Vidra RL, Shear TH. 2008. Thinking locally for urban forest restoration: a simple method links exotic species invasion to Local Landscape Structure. Restor Ecol 16 (2): 217-220.

Wardani M, Susilo A. 2016. Description of habitat, morphology and chemical compounds of Shorea balangeran Burck in Bangka Belitung Forest. Buletin Plasma Nutfah 22 (2): 81-92. [Indonesia]

Widiyatmoko R, Wasis B, Prasetyo LB. 2017. Analysis of revegetation plant growth in post-mining silica land Holcim Educational Forest Cibadak, Sukabumi, West Java. Jurnal Pengelolaan Sumberdaya Alam dan Lingkungan 7 (1): 79-88. [Indonesia]

Yusuf M, Arisoesilaningsih E. 2017. Exotic plant species attack revegetation plants in post-coal mining areas. AIP Conference Proceeding of $8^{\text {th }}$ International Conference on Global Resource Conservation. 1908, 040002 (2017); doi: 10.1063/1.5012716.

Zipper CE, Burger JA, Skousen JG, Angel PN, Barton CD, Davis V, Franklin JA. 2011. Restoring forest and associated ecosystem services on Appalachian coal surface mines. Environ Manag 47: 751-765. 